\title{
Flux of amino acids and peptides across the portal vein-drained tissue of pigs
}

\author{
W.R. Caine ${ }^{1,2}$, M.W. A.Verstegen ${ }^{1,4}$, W.C. Sauer ${ }^{2}$, S. Tamminga ${ }^{1}$ \\ and $P$. van Leeuwen ${ }^{3}$ \\ 'Wageningen Institute of Animal Sciences, Animal Nutrition Group, \\ Wageningen Agricultural University \\ Marijkeweg 40, 6709 PG Wageningen. The Netherlands \\ 'Department of Agricultural, Food and Nutritional Sciences, \\ Universitv of Alberta \\ Edmonton, Alberta, T6G 2P5, Canada \\ ${ }^{3}$ TNO-Nutrition and Food Research Institute, \\ Department of Animal Nutrition and Meat Technology (ILOB) \\ P.O. Box \#15, 6700 AA Wageningen, The Netherlands
}

(Received 20 August 1998; accepted 19 November 1998)

\begin{abstract}
An experiment was carried out to determine the flux of amino acids across the portal veindrained tissue into and out of the plasma and red blood cell free amino acid pools and the plasma peptide pool of the portal vein blood of growing pigs. Four pigs, fitted with catheters in a carotid artery and the portal and mesenteric veins, were fed a maize starch-based diet with wheat gluten as protein source. The feed was given daily at the level of $2 \%$ body weight as a wet mash $(1: 2, w / v$ water) in two equal meals at 08.00 and $16.00 \mathrm{~h}$. After 5 -d adaptation to diet, the pigs received their $08.00 \mathrm{~h}$ meal and, subsequently, were not fed again for $28 \mathrm{~h}$. At 4 (fed) and 28 (unfed) h after receiving the meal, simultaneous $8 \mathrm{~mL}$ blood samples were taken from the portal vein and carotid artery of each pig. The flow of whole blood and plasma were determined by the indicator-dilution method, using continuous infusion of $p$-aminohippuric acid into the mesenteric vein. Blood sampling and flow measurements were repeated $5 \mathrm{~d}$ later. Total flux of amino acids were higher $(\mathrm{P}=0.02)$ in the plasma $(55.7 \mathrm{vs} 1.9 \mathrm{mmol} / \mathrm{h})$ and plasma peptide $(123.2 \mathrm{vs}-1.2 \mathrm{mmol} / \mathrm{h})$ pools of portal vein blood of fed compared to unfed pigs, respectively. Corresponding total flux in the red blood cell pool $(77.5 \mathrm{vs} 5.9 \mathrm{mmol} / \mathrm{h})$ was not statistically significant $(\mathrm{P}=0.29)$ because of a large standard error
\end{abstract}

\footnotetext{
${ }^{4}$ Corresponding author
} 
due to inconsistency between the pigs and accumulated analytical variation. A substantial proportion of the amino acids in the plasma peptide pool of portal vein blood of fed pigs were of dictary origin based on a similar amino acid profile to that of wheat gluten. In conclusion, the plasma free amino acid and plasma peptide pools, and probably the red blood cell free amino acid pool, of portal vein blood are involved in the flux of amino acids across the portal vein-drained tissue of pigs.

KEY WORDS: pigs, flux of amino acids, peptides

\section{INTRODUCTION}

Blood plasma is conventionally considered to be the main pool of flux exchange and transport of free amino acids. However, flux of amino acids into and out of the red blood cells have been reported across the gastrointestinal and liver tissues of dogs (Elwyn et al., 1968), rats (Boullin et al., 1973; Galibois et al., 1991) and sheep (Heitmann and Bergman, 1980). Moreover, the flux of amino acids across the gastrointestinal tissue was substantially higher in the form of plasma peptides than that of the plasma and red blood cell pools of the portal vein blood of fed and unfed calves (Koeln et al., 1993). The relationship between gastrointestinal flux of amino acids and the different blood transport pools has not been reported in pigs. This is surprising considering that diet formulations for pigs are usually based on ileal amino acid digestibilities of dietary protein (Sauer and Ozimek, 1986). The nutritive value of protein sources for pigs are also increasingly being evaluated by determining true ileal digestibilities of amino acids (Caine et al., 1997). This further emphasizes the importance of understanding what proportion of amino acids absorbed from the gastrointestinal tract are of dietary or endogenous origin. Indeed, Rerat (1990) has suggested that ileal amino acid digestibilities do not adequately represent the nutritive value of protein sources for pigs. Instead, he advocates the flux of amino acids into portal vein blood of pigs as a better indication of their availability for protein tissue synthesis. In this respect, Rerat et al. (1988) reported a higher and more rapid appearance of amino acids in the portal vein blood of pigs receiving a duodenal infusion of milk protein peptide hydrolysate than a free amino acid solution of the same composition. These authors did not report flux of amino acids between the different blood transport pools but their results suggest that plasma peptides may be absorbed from the gastrointestinal tract of pigs.

The objective of this study was to determine the flux of amino acids across the portal vein-drained tissue into and out of the plasma, red blood cell and plasma peptide pools of the portal vein blood of fed and unfed pigs. 


\section{MATERIAL AND METHODS}

\section{Animals and diets}

The experiment was carried-out according to a repeated measures design, in conjunction with a study to evaluate ${ }^{15} \mathrm{~N}$-enrichment of the blood plasma free amino acid pool of pigs using intravenous infusion versus oral dosing of ${ }^{15} \mathrm{~N}-\mathrm{L}$-leucine (W.R. Caine, unpublished results). Four cross-bred barrows [(Dutch Landrace $x$ Yorkshire) $x$ Finnish Landrace] with an average body weight ( \pm SE) of $54.2( \pm 1.2)$ $\mathrm{kg}$ were fitted with indwelling catheters in the portal and mesenteric veins as described by van Leeuwen et al. (1995) and in an occluded carotid artery as described by Yen and Killefer (1987). The pigs were housed in individual metabolism crates $(80 \times 180 \mathrm{~cm})$ in a temperature-controlled $\left(23 \pm 1^{\circ} \mathrm{C}\right)$ room at the TNO-ILOB Institute, Wageningen. The experimental diet was maize starch-based with wheat gluten as the only protein source. The diet contained $152.5 \mathrm{~g}$ crude protein $/ \mathrm{kg}$, as fed to the pigs. Soya oil was added so that the diet exceeded Centraal Veevoederbureau (CVB, 1998) standards for digestible energy. Vitamins and minerals were supplemented to the diet to meet or exceeded CVB (1998) standards. Formulation and nutrient concentrations of the diet are presented in Table 1.

The pigs were fed at a daily level of $2 \%$ body weight in two equal meals at 08.00 and $16.00 \mathrm{~h}$ throughout the experiment. Feed was given as a wet mash (1:2, $\mathrm{w} / \mathrm{v}$ water). No additional water was available to the pigs. Each experimental period lasted $7 \mathrm{~d}$. From $\mathrm{d} 1$ to 5 , the pigs were fed the experimental diet. At $06.00 \mathrm{~h}$ on d 6 the mesenteric vein catheter of each pig was connected to a perfusion pump (B. Braun Melsungen AG, FRG) for priming and subsequent continuous infusion of $0.9 \mathrm{~g} \mathrm{NaCl} / \mathrm{L}$ solution containing $10 \mathrm{~g} / \mathrm{L} p$-aminohippuric acid $(\mathrm{PAH})$ as blood flow marker. A swivel apparatus as described by van Kleef (1993) allowed the pigs to move freely during the infusion of the PAH solution. Four $h$ after receiving the $08.00 \mathrm{~h}$ morning meal on $\mathrm{d} 6,8 \mathrm{~mL}$ blood samples were simultaneously withdrawn from the portal vein and carotid artery catheters of each pig. Infusion of the PAH was then discontinued. The pigs did not receive their next two meals; $16.00 \mathrm{~h}$ on d 6 and $08.00 \mathrm{~h}$ on $\mathrm{d} 7$. Infusion of the PAH solution was repeated on d 7, as previously described, until $12.00 \mathrm{~h}$ ( $28 \mathrm{~h}$ after receiving the morning meal on the previous day) when simultaneous blood samples were again withdrawn from the pigs. After collection of the blood samples the pigs were immediately given a meal. Blood samples collected at 4 and $28 \mathrm{~h}$ after receiving the $08.00 \mathrm{~h}$ morning meal represented fed and unfed status of the pigs, respectively. The pigs were fed for an additional $5 \mathrm{~d}$ and then a second set of blood samples were collected at 4 and $28 \mathrm{~h}$ after receiving a morning meal, as previously described.

The experimental proposal and surgical procedures were approved by the TNO Committee for Animal Welfare. 
TABLE 1

Formulation and nutrient concentration of the experimental diet as fed to the pigs

\begin{tabular}{|c|c|c|c|}
\hline \multirow{2}{*}{$\frac{\text { Ingredient, } \mathrm{g} / \mathrm{kg}}{\text { Maize starch }}$} & \multicolumn{3}{|c|}{ Nutrient, $\mathrm{g} / \mathrm{kg}^{\prime}$} \\
\hline & 525 & Dry matter & 888.1 \\
\hline Wheat gluten & 178 & Crude protein & 152.5 \\
\hline Dextrose & 150 & Amino acids & \\
\hline Ccllulose & 50 & indispensable & \\
\hline $\mathrm{CaHPO}_{4} \cdot \mathrm{H}_{2} \mathrm{O}$ & 25 & Arg & 7.1 \\
\hline Soya oil & 20 & His & 4.5 \\
\hline $\mathrm{KHCO}_{3}$ & 20 & Iso & 6.6 \\
\hline $\mathrm{CaCO}_{3}$ & 10 & Leu & 13.5 \\
\hline Vitamin/mincral premix ${ }^{2}$ & 10 & Lys & 3.8 \\
\hline $\mathrm{NaCl}$ & 5 & Met & 2.5 \\
\hline $\mathrm{NaHCO}_{3}$ & 5 & Phe & 10.0 \\
\hline \multirow{9}{*}{$\mathrm{MgSO}_{4} \cdot 7 \mathrm{H}_{2} \mathrm{O}_{2}$} & & Thr & 3.6 \\
\hline & & Val & 8.4 \\
\hline & & Dispensable & \\
\hline & & Ala & 4.2 \\
\hline & & $A s p+A s n$ & 5.9 \\
\hline & & $\mathrm{Glu}+\mathrm{Gln}$ & 63.0 \\
\hline & & Gly & 11.4 \\
\hline & & Ser & 7.5 \\
\hline & & Tyr & 3.2 \\
\hline
\end{tabular}

I - nutrient concentration as analyzed. Crude protein ( $\mathrm{N} \times 6.25)$

2 - provided the following $(\mathrm{mg} / \mathrm{kg}$ of diet): choline, $1000.0 ;$ ascorbic acid, $50.0 ; \alpha$-tocopheryl acctate, 40.0; niacin, 30.0; d-pantothenic acid, 12.0; riboflavin, 5.0; retinyl palmitic acid, 4.95; menadione dimethyl-pyrimidinol bisulphite, 3.0; pyridoxal-phosphate, 3.0; thiamin, 2.0; folacin, 1.0; d-biotin, 0.1; cholecalcifcrol, 0.045 ; cyanocobalamin, $0.04 ; \mathrm{ZnSO}_{4} \cdot 2 \mathrm{H}_{2} \mathrm{O}, 300.0 ; \mathrm{MnO}_{2}$, 15.0; $\mathrm{FeSO}_{4} \cdot 7 \mathrm{H} 2 \mathrm{O}, 400.0 ; \mathrm{CoSO}_{4} \cdot 5 \mathrm{H}_{2} \mathrm{O}, 2.5 ; \mathrm{KI}, 0.5 ; \mathrm{CuSO}_{4} \cdot 5 \mathrm{H}_{2} \mathrm{O}, 35.0 ; \mathrm{Na}_{2} \mathrm{SeO}_{3} \cdot 5 \mathrm{H}_{2} \mathrm{O}, 0.2$; tylosin, 40.0

\section{Chemical analyses}

A schematic diagram of the processing of blood samples representing the plasma and red blood cell free amino acid pools and the plasma peptide pool is presented in Figure 1. Samples of blood, stored on ice immediately following withdrawal from the pigs, were processed within $30 \mathrm{~min}$ after their collection. Packed cell volume was determined on the blood samples using a microhaematocrit. A $2 \mathrm{~mL}$ aliquot, representing whole blood, was deproteinized by vortexing (Janke and Kunkel IKA-WERK, Model ${ }^{\not}$ VF-1, Staufen im Breisgan, D) in $18 \times 150-\mathrm{mm}$ test tubes with the slow addition of an equal volume of cold $1.5 \mathrm{M}$-trichloroacetic acid (chilled in ice water). The test tubes were centrifuged at $4^{\circ} \mathrm{C}$ and $3000 \mathrm{x} \mathrm{g}$ for $10 \mathrm{~min}$ and the supernatant transferred to a second test tube and frozen at $-40^{\circ} \mathrm{C}$. 


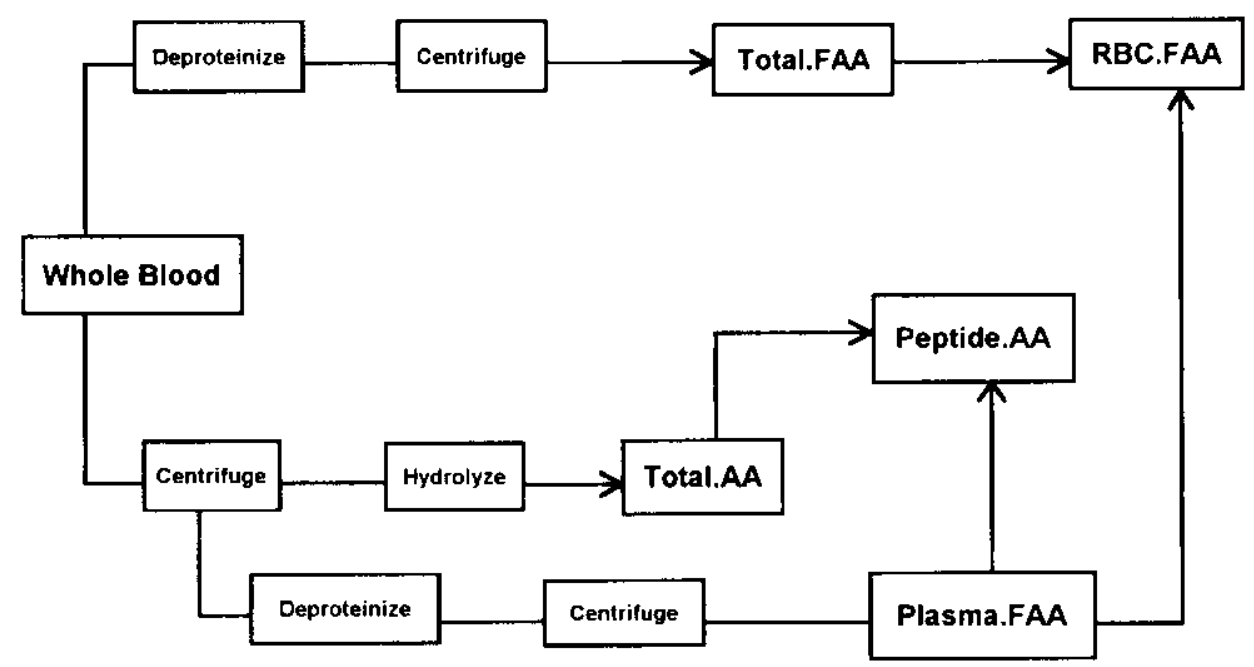

Figure 1. A schematic diagram of the processing of whole blood samples to determine the concentration of plasma free amino acids (Plasma.FAA) and red blood cell free amino acids (RBC.FAA = Total.FAA - Plasma.FAA) and concentration of amino acids (AA) of the plasma peptides (Peptide AA $=$ Total.AA - Plasma.FAA)

The remaining portion of the blood samples were centrifuged at $4^{\circ} \mathrm{C}$ and $3000 \mathrm{xg}$ for $10 \mathrm{~min}$ to remove the red blood cells and the plasma subdivided into three aliquots. Two $1 \mathrm{~mL}$ aliquots were frozen at $-40^{\circ} \mathrm{C}$ until later analysis for $\mathrm{PAH}$ and plasma peptide amino acid concentrations, respectively. A $2 \mathrm{~mL}$ aliquot, representing plasma, was deproteinized as described for whole blood and frozen at $-40^{\circ} \mathrm{C}$. Subsequently, the whole blood and plasma aliquots were freeze-dried and stored at $-20^{\circ} \mathrm{C}$ until amino acid analysis.

The dry matter content of the diet was determined according to AOAC (1990). The crude protein $(\mathrm{N} \times 6.25)$ content in the diet was measured with an Automated Nitrogen Analyzer (FP-428 Nitrogen Determinator, Leco ${ }^{*}$ Corporation, St. Joseph, MI). Analysis of amino acid concentrations in blood samples and the diet were performed by a fluorometric method involving pre-column derivatization with $o$-phthaldialdehyde and analysis by High Performance Liquid Chromatography (HPLC) according to Sedgwick et al. (1991). A Varian 5000 HPLC system with a Varian 9090 autosampler and a Varian Fluorichrom detector (excitation $340 \mathrm{~nm}$, emission $450 \mathrm{~nm}$; Varian Canada Inc., Mississauga, $O N$ ) was used for the analysis. Whole blood and plasma samples were reconstituted in $2 \mathrm{~mL}$ of deionized water prior to analysis. The concentration of amino acids in the plasma peptides and the diet were determined by hydrolyzing $1 \mathrm{~mL}$ of plasma or $100 \mathrm{mg}$ of the diet in $13 \times 100-\mathrm{mm}$ screw-capped culture tubes containing $3 \mathrm{~mL}$ of $6 \mathrm{M} \mathrm{HCl}$. The tubes were purged with nitrogen before sealing the screw cap and then incubated in an oven at $100^{\circ} \mathrm{C}$ for $24 \mathrm{~h}$. Concentrations of amino acids were determined in dupli- 
cate aliquots of the deproteinized whole blood and plasma samples or hydrolysates, injected on a Supelcosil 3 micron LC-18 reverse phase column $(4.6 \times 150-\mathrm{mm}$; Supelco, Sigma-Aldrich Canada Ltd., Mississauga, ON) equipped with a Supelco LC-18 reverse phase 20 to 40 micron guard column $(4.6 \times 50-\mathrm{mm})$. Peaks for amino acids were recorded and integrated with the EZchrom ${ }^{\mathrm{TM}}$ Chromatography Data System (version 2.12, Shimadzu Scientific Instruments Inc., Columbia, MD). Difference in the amino acid concentrations of deproteinized whole blood and the plasma hydrolysates from that of deproteinized plasma represented values for the red blood cell and plasma peptide pools, respectively. Concentration of amino acids was reported on a whole blood basis with values for the plasma and plasma peptide pools corrected for a $20 \%$ content of plasma in the packed cell volume according to Koeln et al. (1993).

Calculation of portal vein blood flow and portal vein-drained tissue flux of amino acids

The concentration of PAH in plasma samples was analyzed according to the procedure described by Katz and Bergman (1969). The flow of whole blood and plasma in the portal vein were calculated by the indicator-dilution method, using PAH as blood flow marker and the equations of Yen and Killefer (1987). Flux of amino acids across the portal vein-drained tissue were calculated as the difference between the respective concentrations in the portal vein and carotid artery blood pools, multiplied by the portal vein blood flow rate as described by Koeln et al. (1993).

\section{Statistical analysis}

The concentration and flux of amino acids and portal vein blood flows were subjected to analysis of variance using a split-plot model (General Linear Model Procedure; Statistical Analysis System Institute Inc., 1990) with the respective blood samples collected from the pigs during the experimental periods considered as repeated measurements. The statistical model was, as follows:

$$
Y_{i j k}=\mu+T_{i}+P_{j}+A_{k}\left(T_{i}\right)+\left(T_{i} \times P_{j}\right)+\varepsilon_{i j k}
$$

where; $Y_{i j k}$, dependent variable; $\mu$, overall mean; $T$, time after feeding $(i=2)$; $P$, experimental period $(\mathrm{j}=2) ; \mathrm{A}$, animal $(\mathrm{k}=4)$ and $\varepsilon_{\mathrm{ijk}}$, residual error. The effect of time after feeding $(T)$ was tested against animals within time after feeding $[A(T)]$. The effect of period (P) and the time after feeding by period interaction ( $\mathrm{T} \times \mathrm{P}$ ) were tested against the residual error $\left(\varepsilon_{\mathrm{ij} k}\right)$. Means of whole blood and plasma flow in the portal vein and the concentration and flux of amino acids in the fed and unfed pigs were compared using the Students $t$-test according to 
Steel and Torrie (1980). The Students' $t$-test was also used to determine if the flux of amino acids from the portal vein-drained tissue into and out of the different transport pools of portal vein blood differed from zero. The relationship between the composition of amino acids in the plasma peptide pool of portal vein blood of the fed pigs and amino acid compositions of the diet and endogenous secretions were determined using the linear-regression analysis procedure of the Statistical Analysis System Institute Inc. (1990). Means were considered to be different when the P value was less than 0.05 . There was a trend for means to be different when the P value was less than 0.1 .

\section{RESULTS}

With the exception of lysine and threonine amino acid concentrations in the diet met or exceeded requirements for optimum growth in pigs according to the CVB (1998). The pigs were fed at a level slightly above maintenance to minimize their weight gain while maintaining a positive nutritional status. The average daily gain of the pigs was $87.5( \pm 12.7) \mathrm{g} / \mathrm{d}$ during the experiment.

There was usually no effect $(\mathrm{P}>0.1)$ of period for whole blood and plasma flow rates or arterial and portal vein blood pool concentrations of the pigs. The flux of amino acids in the different portal vein blood pools of the pigs were also similar between the two periods.

\section{Portal vein blood flow}

The flow of whole blood and plasma in the portal vein of the fed and unfed pigs are presented in Table 2 . The flow rates of the fed ( $4 \mathrm{~h}$ after feeding) pigs were higher $(\mathrm{P}<0.05)$ than that of unfed $(28 \mathrm{~h}$ after feeding) pigs. The average packed cell volume in arterial $(29.0 \pm 0.7 \%)$ and portal vein $(29.3 \pm 0.8 \%)$ blood was similar $(\mathrm{P}>0.1)$.

TABLE 2

Flow rate of whole blood and plasma in the portal vein of fed and unfed pigs

\begin{tabular}{lcc}
\hline Time after feeding, $\mathrm{h}$ & Whole blood flow, $\mathrm{L} / \mathrm{min}^{1}$ & Plasma flow, $\mathrm{L} / \mathrm{min}^{1}$ \\
\hline 4.0, fed & 2.67 & 2.20 \\
28.0, unfed & 1.77 & 1.43 \\
$\mathrm{SE}^{2}$ & 0.34 & 0.28 \\
Overall mean & 2.22 & 1.82 \\
\hline
\end{tabular}

1 - means of fed and unfed pigs were different $(\mathrm{P}<0.05)$

$2^{2}-$ standard error of the mean $(n=8)$ 
TABLE 3

Concentration $(\mu \mathrm{mol} / \mathrm{L})$ of amino acids in the plasma, red blood cell and plasma peptide pools of arterial blood of fed and unfed pigs

\begin{tabular}{|c|c|c|c|c|c|c|c|c|c|c|c|c|}
\hline & \multicolumn{4}{|c|}{ Plasma } & \multicolumn{4}{|c|}{ Red Blood Cells } & \multicolumn{4}{|c|}{ Plasma Peptides } \\
\hline & fed & unfed & $\mathrm{SE}^{\prime}$ & $\mathrm{P}^{2}$ & fed & unfed & $\mathrm{SE}^{\prime}$ & $\mathbf{P}^{2}$ & fed & unfed & $\mathrm{SE}^{\prime}$ & $\mathrm{P}^{2}$ \\
\hline $\mathrm{TAA}^{3}$ & 2185.8 & 1535.7 & 122.5 & 0.01 & 850.8 & 575.1 & 66.4 & 0.03 & 542.2 & 736.6 & 207.5 & 0.53 \\
\hline $1 \mathrm{AA}^{3}$ & 811.3 & 606.3 & 69.4 & 0.08 & 130.6 & 123.6 & 24.5 & 0.85 & 129.5 & 217.8 & 76.8 & 0.45 \\
\hline Arg & 83.8 & 53.5 & 6.2 & 0.01 & 4.9 & -1.4 & 4.5 & 0.36 & 5.2 & 13.2 & 7.1 & 0.45 \\
\hline His & 46.5 & 28.4 & 5.4 & 0.05 & 14.7 & 4.3 & 6.3 & 0.29 & 11.4 & 14.4 & 4.8 & 0.67 \\
\hline Iso & 96.6 & 72.0 & 6.9 & 0.05 & 2.2 & 6.9 & 1.9 & 0.12 & 12.1 & 20.9 & 8.1 & 0.47 \\
\hline Leu & 133.5 & 82.6 & 12.6 & 0.03 & 16.2 & 14.4 & 2.5 & 0.62 & 40.0 & 48.4 & 13.4 & 0.68 \\
\hline Lys & 32.8 & 78.1 & 10.3 & 0.02 & 54.8 & 50.4 & 7.6 & 0.70 & 28.4 & 45.0 & 12.5 & 0.38 \\
\hline Met & 0.0 & 0.0 & 0.0 & 1.00 & 0.0 & 0.0 & 0.0 & 1.00 & & & & \\
\hline Phe & 88.1 & 39.8 & 7.5 & 0.01 & 4.0 & 3.7 & 0.9 & 0.84 & 20.6 & 24.7 & 7.7 & 0.72 \\
\hline Thr & 155.3 & 115.0 & 18.2 & 0.17 & 17.8 & 25.0 & 6.8 & 0.49 & -19.5 & 12.8 & 14.7 & 0.17 \\
\hline $\operatorname{Trp}$ & 1.9 & 0.7 & 0.4 & 0.06 & 1.6 & 0.9 & 0.7 & 0.53 & & & & \\
\hline Val & 172.9 & 136.2 & 16.5 & 0.17 & 14.4 & 19.5 & 4.4 & 0.44 & 23.8 & 39.1 & 12.9 & 0.43 \\
\hline $\mathrm{DAA}^{3}$ & 1374.6 & 929.4 & 68.2 & 0.01 & 720.2 & 451.6 & 48.5 & 0.01 & 412.7 & 518.8 & 132.5 & 0.59 \\
\hline Ala & 279.0 & 157.9 & 19.6 & 0.01 & 39.8 & 19.9 & 3.5 & 0.01 & 64.9 & 61,1 & 20.7 & 0.90 \\
\hline Asn & 49.0 & 32.7 & 3.6 & 0.02 & -2.1 & 0.8 & 1.5 & 0.22 & & & & \\
\hline Asp & 8.6 & 4.1 & 0.4 & 0.01 & 21.0 & 16.1 & 2.7 & 0.25 & 54.5 & 71.9 & 15.0 & 0.44 \\
\hline Cit & 19.0 & 3.6 & 2.1 & 0.01 & 9.9 & 2.1 & 1.7 & 0.02 & & & & \\
\hline Gln & 96.4 & 54.4 & 7.8 & 0.01 & 28.6 & 14.8 & 7.9 & 0.26 & & & & \\
\hline Glu & 105.0 & 47.5 & 6.9 & 0.01 & 37.4 & 39.6 & 7.1 & 0.83 & 296.7 & 189.2 & 42.1 & 0.12 \\
\hline Gly & 474.5 & 427.1 & 35.1 & 0.38 & 223.0 & 90.6 & 20.3 & 0.01 & 17.7 & 158.5 & 49.5 & 0.09 \\
\hline Orn & 77.9 & 24.9 & 3.3 & 0.01 & 57.2 & 30.0 & 5.0 & 0.01 & & & & \\
\hline Ser & 122.8 & 91.9 & 8.0 & 0.03 & 23.3 & 13.8 & 2.8 & 0.05 & 16.7 & 47.6 & 15.7 & 0.21 \\
\hline Tau & 65.2 & 49.8 & 5.9 & 0.12 & 269.6 & 209.8 & 24.5 & 0.13 & & & & \\
\hline Tyr & 77.4 & 35.6 & 5.9 & 0.01 & 12.5 & 14.2 & 1.9 & 0.54 & -26.3 & -13.9 & 8.3 & 0.34 \\
\hline
\end{tabular}

' - standard error of the mean $(n=8)$

2 - probability that the means of fed and unfed pigs are different

3 - total amino acids, TAA; indispensable amino acids, IAA; dispensable amino acids, DAA

Concentration of amino acids in the transport pools of arterial and portal vein blood

The concentration of amino acids in the plasma, red blood cell and plasma peptide pools of arterial and portal vein blood are presented in Tables 3 and 4, respectively. The concentrations of methionine and tryptophan in the blood samples were low and, therefore, not reported. In both the fed and unfed pigs 40 to $60 \%$ of total amino acids were in the plasma pool of arterial and portal vein blood with the remaining 40 to $60 \%$ more or less equally distributed between red blood cells and plasma peptides. Negative values for tyrosine concentration in the plasma peptide pool of arterial (Table 3 ) and portal vein (Table 4) blood of the fed and 
TABLE 4

Concentration ( $\mu \mathrm{mol} / \mathrm{L}$ ) of amino acids in the plasma, red blood cell and plasma peptide pools of portal vein blood of fed and unfed pigs

\begin{tabular}{|c|c|c|c|c|c|c|c|c|c|c|c|c|}
\hline & \multicolumn{4}{|c|}{ Plasma } & \multicolumn{4}{|c|}{ Red Blood Cells } & \multicolumn{4}{|c|}{ Plasma Peptides } \\
\hline & fed & unfed & $\mathrm{SE}^{\prime}$ & $\mathbf{P}^{2}$ & fed & unfed & $\mathrm{SE}^{\prime}$ & $\mathrm{P}^{2}$ & fed & unfed & $\mathrm{SE}^{\prime}$ & $\mathrm{P}^{2}$ \\
\hline $\mathrm{TAA}^{3}$ & 2582.2 & 1514.5 & 72.3 & 0.01 & 1676.6 & 649.5 & 481.7 & 0.18 & 1066.5 & 640.5 & 229.9 & 0.24 \\
\hline $\mathrm{IAA}^{3}$ & 966.6 & 588.4 & 55.8 & 0.01 & 366.6 & 141.5 & 143.1 & 0.31 & 289.0 & 181.6 & 93.7 & 0.45 \\
\hline Arg & 103.9 & 51.8 & 4.6 & 0.01 & 21.4 & 2.4 & 10.8 & 0.26 & 18.6 & 10.0 & 7.9 & 0.47 \\
\hline His & 66.4 & 27.5 & 2.8 & 0.01 & 14.2 & 7.8 & 5.1 & 0.40 & 24.9 & 13.3 & 13.5 & 0.57 \\
\hline Iso & 112.5 & 69.2 & 8.1 & 0.01 & 34.8 & 9.2 & 20.2 & 0.41 & 23.8 & 19.9 & 8.6 & 0.76 \\
\hline Leu & 168.7 & 79.3 & 8.8 & 0.01 & 69.0 & 21.1 & 28.1 & 0.27 & 61.8 & 43.2 & 12.3 & 0.33 \\
\hline Lys & 43.9 & 76.7 & 10.3 & 0.07 & 77.1 & 52.4 & 18.9 & 0.39 & 54.8 & 32.0 & 14.7 & 0.32 \\
\hline Met & 0.4 & 0.0 & 0.3 & 0.36 & 0.4 & 0.0 & 0.3 & 0.36 & & & & \\
\hline Phe & 111.0 & 38.2 & 7.1 & 0.01 & 29.0 & 6.2 & 16.7 & 0.37 & 30.2 & 22.6 & 8.0 & 0.52 \\
\hline Thr & 166.7 & 113.1 & 16.1 & 0.06 & 55.8 & 19.1 & 22.1 & 0.28 & 21.5 & 5.4 & 18.3 & 0.56 \\
\hline $\operatorname{Trp}$ & 2.2 & 0.3 & 0.3 & 0.01 & 1.4 & 1.2 & 0.7 & 0.90 & & & & \\
\hline Val & 191.0 & 132.4 & 14.8 & 0.03 & 63.5 & 22.1 & 30.7 & 0.38 & 52.9 & 34.6 & 14.5 & 0.41 \\
\hline $\mathrm{DAA}^{3}$ & 1615.5 & 926.1 & 38.4 & 0.01 & 1310.0 & 508.0 & 340.3 & 0.15 & 777.4 & 458.9 & 141.8 & 0.16 \\
\hline Ala & 360.8 & 160.2 & 19.1 & 0.01 & 145.4 & 25.9 & 65.9 & 0.25 & 42.7 & 49.1 & 23.1 & 0.85 \\
\hline Asn & 61.0 & 33.9 & 3.9 & 0.01 & 15.4 & 1.2 & 10.9 & 0.39 & & & & \\
\hline Asp & 11.8 & 4.5 & 1.8 & 0.03 & 22.9 & 15.4 & 4.5 & 0.29 & 102.8 & 71.8 & 14.4 & 0.18 \\
\hline Cit & 22.8 & 3.8 & 2.4 & 0.01 & 13.0 & 6.1 & 2.8 & 0.14 & & & & \\
\hline Gln & 76.0 & 42.3 & 15.4 & 0.17 & 117.8 & 19.6 & 44.6 & 0.17 & & & & \\
\hline Glu & 104.0 & 43.6 & 6.6 & 0.01 & 72.7 & 42.5 & 17.6 & 0.27 & 476.5 & 177.0 & 24.3 & 0.01 \\
\hline Gly & 564.8 & 434.8 & 20.3 & 0.01 & 366.5 & 109.9 & 89.4 & 0.09 & 110.5 & 125.8 & 51.1 & 0.84 \\
\hline Orn & 85.9 & 24.6 & 3.3 & 0.01 & 93.1 & 28.8 & 19.9 & 0.06 & & & & \\
\hline Ser & 168.8 & 89.2 & 6.3 & 0.01 & 87.1 & 21.4 & 37.0 & 0.25 & 59.7 & 50.6 & 19.2 & 0.75 \\
\hline Tau & 73.5 & 54.6 & 5.4 & 0.05 & 335.4 & 221.8 & 47.6 & 0.14 & & & & \\
\hline Туг & 86.3 & 34.7 & 5.5 & 0.01 & 40.8 & 15.5 & 14.3 & 0.26 & -34.1 & -10.2 & 6.7 & 0.05 \\
\hline
\end{tabular}

I - standard error of the mean $(n=8)$

$?$ - probability that the means of fed and unfed pigs are different

3 - total amino acids, TAA; indispensable amino acids, IAA; dispensable amino acids, DAA

unfed pigs indicate that this amino acid was partly lost during acid hydrolysis. In the same order, there was a negative concentration of threonine in the plasma peptide pool of arterial blood of fed pigs.

The total concentration of amino acids in the plasma $(\mathrm{P}=0.01)$ and red blood cell $(\mathrm{P}=0.03)$ pools of arterial blood of fed pigs were higher than that of unfed pigs. Corresponding plasma peptide pools were similar $(\mathrm{P}=0.53)$. In portal vein blood only the total concentration of amino acids in the plasma free amino acid pool was different $(\mathrm{P}=0.01)$ between fed and unfed pigs. The plasma free amino acid pool concentrations of most of the amino acids were higher $(\mathrm{P}<0.05)$ in the fed than unfed pigs in both arterial and portal vein blood. The exception was lysine 
concentration, which was lower $(\mathrm{P}=0.02)$ in arterial plasma and tended $(\mathrm{P}=0.07)$ to be lower in portal vein plasma of the fed pigs. The difference in alanine concentration between fed and unfed pigs was the highest of the amino acids at 121.1 and $200.6 \mu \mathrm{mol} / \mathrm{L}$ for arterial and portal vein plasma, respectively. The arterial red blood cell concentration of the dispensable amino acids, alanine, citrulline, glycine, ornithine and serine were higher $(\mathrm{P}<0.05)$ in the fed than unfed pigs. None of the portal vein red blood cell free amino acid concentrations were different $(\mathrm{P}>0.05)$ in fed than for unfed pigs, although, there was a trend for an increase in glycine $(\mathrm{P}=0.09)$ and ornithine $(\mathrm{P}=0.06)$.

\section{Flux of amino acids across the portal vein-drained tissue}

The flux of total and indispensable amino acids across the portal vein-drained tissue into and out of the plasma, red blood cell and plasma peptide pools of the portal vein blood of fed and unfed pigs are presented in Table 5. The total flux of amino acids in the plasma $(55.7 \mathrm{mmol} / \mathrm{h})$ and plasma peptide $(123.2 \mathrm{mmol} / \mathrm{h})$ pools of fed pigs differed $(\mathrm{P}=0.01)$ from zero and were higher $(\mathrm{P}=0.02)$ than those of unfed pigs. Total flux of amino acids $(77.5 \mathrm{mmol} / \mathrm{h})$ in the red blood cell free amino acid pool of fed pigs did not reach a statistically significant $(\mathrm{P}=0.13)$ difference from zero and were not different $(P=0.29)$ than that of the red blood cell free amino acid pool $(5.9 \mathrm{mmol} / \mathrm{h})$ of unfed pigs. Total flux of amino acids in all of the blood pools of unfed pigs did not differ $(\mathrm{P}>0.1)$ from zero. The total flux of indispensable amino acids was higher in the plasma $(\mathrm{P}=0.02)$ and plasma peptide $(\mathrm{P}=0.05)$ pools of fed compared to unfed pigs. Although, there was usually no difference $(\mathrm{P}>0.1)$ between fed and unfed pigs for indispensable amino acids with a low concentration in the diet.

The flux of dispensable amino acids across the portal vein-drained tissue into and out of the plasma, red blood cell and plasma peptide pools of the portal vein blood of fed and unfed pigs are presented in Table 6 . The flux of dispensable amino acids was different $(\mathrm{P}=0.01)$ from zero in the plasma and plasma peptide pools of fed pigs. Alanine, glycine and serine accounted for 35,34 and $20 \%$, respectively, of the total flux of dispensable amino acids in the plasma free amino acid pool of the fed pigs.

\section{DISCUSSION}

The objective of the experiment was to determine the role of the different blood transport pools during digestion and absorption of wheat gluten as a protein source for fed pigs vs unfed pigs. Wheat gluten was chosen as the protein source because the amino acids are almost completely digested and absorbed (Sarwar et al., 1989; 
TABLE 5

Flux $(\mathrm{mmol} / \mathrm{h})$ of total and indispensable amino acids across the portal vein-drained tissue into and out of the plasma, red blood cell and plasma peptide pools of the portal vein blood of fed and unfed pigs.

\begin{tabular}{|c|c|c|c|c|c|c|c|c|c|c|c|c|c|c|c|c|c|c|}
\hline & \multicolumn{6}{|c|}{ Plasma } & \multicolumn{6}{|c|}{ Red Blood Cells } & \multicolumn{6}{|c|}{ Plasma Peptide } \\
\hline & fed' & $\mathrm{P}^{2}$ & unfed & $\mathrm{P}^{2}$ & $\mathrm{SE}^{3}$ & $\mathrm{P}^{4}$ & Fed & $\mathrm{P}^{2}$ & unfed & $\mathrm{P}^{2}$ & $\mathrm{SE}^{3}$ & $\mathrm{P}^{4}$ & fed & $\mathrm{P}^{2}$ & unfed & $\mathrm{P}^{2}$ & $\mathrm{SE}^{3}$ & $\mathrm{P}^{4}$ \\
\hline $\mathrm{TAA}^{5}$ & 55.8 & 0.01 & 1.9 & 0.88 & 11.7 & 0.02 & 77.6 & 0.13 & 6.0 & 0.89 & 43.6 & 0.29 & 123.2 & 0.01 & -1.2 & 0.96 & 29.6 & 0.02 \\
\hline $\mathrm{IAA}^{5}$ & 22.6 & 0.01 & -0.6 & 0.92 & 5.4 & 0.02 & 21.1 & 0.17 & 1.5 & 0.92 & 13.3 & 0.34 & 37.2 & 0.01 & -0.7 & 0.96 & 10.9 & 0.05 \\
\hline Arg & 2.8 & 0.01 & 0.1 & 0.94 & 0.8 & 0.05 & 1.6 & 0.19 & 0.2 & 0.90 & 1.1 & 0.38 & 3.3 & 0.02 & -0.2 & 0.88 & 1.1 & 0.06 \\
\hline $\mathrm{His}$ & 2.7 & 0.03 & 0.0 & 0.98 & 0.9 & 0.08 & -0.1 & 0.95 & 0.4 & 0.73 & 1.2 & 0.77 & 4.2 & 0.09 & 0.2 & 0.91 & 2.0 & 0.22 \\
\hline Iso & 2.5 & 0.01 & -0.2 & 0.80 & 0.6 & 0.02 & 2.7 & 0.20 & 0.2 & 0.92 & 1.9 & 0.38 & 2.9 & 0.02 & 0.1 & 0.98 & 1.0 & 0.09 \\
\hline Leu & 5.2 & 0.01 & 0.0 & 0.98 & 1.0 & 0.01 & 5.0 & 0.07 & 0.6 & 0.82 & 2.3 & 0.22 & 5.7 & 0.01 & -0.1 & 0.95 & 1.4 & 0.03 \\
\hline Lys & 1.7 & 0.01 & 0.0 & 0.98 & 0.3 & 0.01 & 2.2 & 0.17 & 0.2 & 0.89 & 1.4 & 0.35 & 4.8 & 0.07 & -0.7 & 0.76 & 2.2 & 0.12 \\
\hline Met & 0.1 & 0.21 & 0.0 & 1.00 & 0.1 & 0.36 & 0.1 & 0.21 & 0.0 & 1.00 & 0.0 & 0.36 & & & & & & \\
\hline Phe & 3.3 & 0.01 & -0.1 & 0.92 & 0.5 & 0.01 & 2.1 & 0.23 & 0.2 & 0.89 & 1.5 & 0.43 & 3.0 & 0.02 & 0.0 & 0.98 & 0.9 & 0.06 \\
\hline Thr & 1.6 & 0.19 & -0.1 & 0.90 & 1.1 & 0.29 & 3.4 & 0.19 & -0.6 & 0.79 & 2.3 & 0.26 & 7.9 & 0.01 & 0.0 & 0.99 & 2.2 & 0.05 \\
\hline $\operatorname{Trp}$ & 0.0 & 0.73 & 0.0 & 0.79 & 0.1 & 0.67 & 0.0 & 0.91 & 0.1 & 0.79 & 0.2 & 0.91 & & & & & & \\
\hline Val & 2.7 & 0.02 & -0.2 & 0.82 & 0.9 & 0.06 & 4.1 & 0.21 & 0.3 & 0.92 & 2.9 & 0.39 & 6.0 & 0.01 & -0.1 & 0.97 & 1.5 & 0.03 \\
\hline
\end{tabular}

1 - negative means suggest that more of the total, indispensable or individual amino acids entered than left the portal vein-drained tissue

${ }^{2}$ - probability that the mean does not differ from zero

3 - standard error of the mean $(\mathrm{n}=8)$

${ }^{4}$ - probability that the means of fed and unfed pigs are different

s - total amino acids, TAA; indispensable amino acids, IAA 
Flux (mmol/h) of dispensable amino acids across the portal vein-drained tissue into and out of the plasma, red blood cell and plasma peptide pools of the portal vein blood of fed and unfed pigs

\begin{tabular}{|c|c|c|c|c|c|c|c|c|c|c|c|c|c|c|c|c|c|c|}
\hline & \multicolumn{6}{|c|}{ Plasma } & \multicolumn{6}{|c|}{ Red Blood Cells } & \multicolumn{6}{|c|}{ Plasma Peptide } \\
\hline & fed' & $\mathrm{P}^{2}$ & unfed & $\mathrm{P}^{2}$ & $\mathrm{SE}^{3}$ & $\mathrm{P}^{4}$ & Fed & $\mathrm{P}^{2}$ & unfed & $\mathrm{P}^{2}$ & $\mathrm{SE}^{3}$ & $\mathrm{P}^{+}$ & fed & $\mathrm{P}^{2}$ & unfed & $\mathrm{P}^{2}$ & $S E^{3}$ & $\mathrm{P}^{4}$ \\
\hline $\mathrm{DAA}^{5}$ & 33.2 & 0.01 & 2.4 & 0.74 & 6.9 & 0.02 & 56.5 & 0.12 & 4.6 & 0.89 & 31.2 & 0.28 & 86.0 & 0.01 & -0.5 & 0.96 & 19.0 & 0.01 \\
\hline Ala & 11.6 & 0.01 & 0.6 & 0.58 & 1.0 & 0.01 & 9.3 & 0.21 & 0.6 & 0.94 & 6.7 & 0.39 & 0.8 & 0.84 & -0.7 & 0.84 & 3.6 & 0.78 \\
\hline Asn & 1.8 & 0.01 & 0.2 & 0.56 & 0.4 & 0.03 & 1.4 & 0.25 & 0.0 & 0.99 & 1.1 & 0.40 & & & & & & \\
\hline Asp & 0.6 & 0.10 & 0.1 & 0.80 & 0.3 & 0.28 & -0.5 & 0.21 & -0.1 & 0.83 & 0.3 & 0.43 & 10.3 & 0.01 & 0.5 & 0.86 & 2.9 & 0.06 \\
\hline $\mathrm{Cit}$ & 0.4 & 0.08 & 0.1 & 0.82 & 0.2 & 0.24 & 0.2 & 0.47 & 0.4 & 0.27 & 0.3 & 0.76 & & & & & & \\
\hline Gln & -1.7 & 0.59 & -1.2 & 0.69 & 2.9 & 0.92 & 6.3 & 0.10 & 0.5 & 0.89 & 3.2 & 0.25 & & & & & & \\
\hline Glu & -0.5 & 0.44 & -0.4 & 0.50 & 0.6 & 0.94 & 3.8 & 0.05 & 0.5 & 0.77 & 1.5 & 0.17 & 38.0 & 0.01 & 0.0 & 0.99 & 6.9 & 0.01 \\
\hline Gly & 11.2 & 0.01 & 2.4 & 0.46 & 3.0 & 0.08 & 16.4 & 0.14 & 0.9 & 0.93 & 9.7 & 0.30 & 26.0 & 0.02 & -1.9 & 0.82 & 7.8 & 0.05 \\
\hline Orn & 0.8 & 0.04 & 0.0 & 0.96 & 0.3 & 0.11 & 4.0 & 0.06 & -0.1 & 0.98 & 1.7 & 0.15 & & & & & & \\
\hline Ser & 6.5 & 0.01 & 0.1 & 0.94 & 1.1 & 0.01 & 5.9 & 0.14 & 0.6 & 0.87 & 3.4 & 0.32 & 11.3 & 0.01 & 1.1 & 0.60 & 1.9 & 0.01 \\
\hline Tau & 1.0 & 0.14 & 0.7 & 0.31 & 0.6 & 0.68 & 7.4 & 0.11 & 1.2 & 0.77 & 4.0 & 0.31 & & & & & & \\
\hline Tyr & 1.4 & 0.03 & 0.0 & 0.98 & 0.5 & 0.08 & 2.5 & 0.12 & 0.1 & 0.95 & 1.4 & 0.27 & -0.4 & 0.67 & 0.5 & 0.61 & 1.0 & 0.51 \\
\hline
\end{tabular}

- negative means suggest that more of the dispensable or individual amino acids entered than left the portal vein-drained tissuc

2 - probability that the mean does not differ from zero

3 - standard error of the mean $(\mathrm{n}=8)$

${ }^{4}$ - probability that the means of fed and unfed pigs are different

$s$ - dispensable amino acids, DAA 
CVB, 1998). It should also be mentioned that the amino acid concentrations of red blood cells and plasma peptides were calculated as the difference between their concentrations in deproteinized whole blood and acid hydrolysates of plasma, respectively, and those of plasma (Figure 1). Variation of data due to inconsistency between the pigs and analytical variation in the estimation of the red blood cell and plasma peptide pools accumulated, resulting in large standard errors that often prevented probable differences from being statistically significant.

Whole blood flow rates in the portal vein were similar to values previously reported for fed (Rerat et al., 1988) and unfed (Yen and Killefer, 1987) pigs of similar weight. The metabolic fate of a large proportion of the dispensable amino acids in the portal vein blood of the pigs was probably oxidation or gluconeogenesis in the liver. In this respect, a large difference in the alanine concentration of the portal vein blood plasma pool of fed compared to unfed pigs emphasizes the metabolic activity of the gastrointestinal tract. Alanine is the predominant amino acid released by the jejunum of growing pigs (Wu et al., 1994). On the other hand, total concentration of amino acids in the arterial red blood cells of fed compared to unfed pigs suggest that this blood pool also has a role in the transport of free amino acids that has been reported for other animals. For instance, transport of amino acids in red blood cells have been reported in cattle (Hanigan et al., 1991; Koeln et al., 1993), dogs (Elwyn, 1966; Elwyn et al., 1968), sheep (Young and Ellory, 1977; Heitmann and Bergman, 1980) and humans (Felig et al., 1973). Moreover, the difference in flux of glutamate and glutamine in the red blood cells of the fed compared to unfed pigs suggests that this blood pool has a specific counter current role to that of plasma in transporting amino acids destine for deamination to $\alpha$-ketoglutarate and subsequent glucose synthesis in the liver. Hanigan et al. (1991) discussed the counter current role of red blood cells for transporting amino acids in the opposite direction of the plasma free amino acid pool in dairy cows. Red blood cells may also have an ancillary function in the renal-intestinal transport and exchange of urea cycle intermediates based on the concentrations of citrulline and ornithine in the arterial red blood cells of the fed pigs. Arginine is not an indispensable amino acid in older pigs because of it's de novo synthesis in the kidneys using citrulline as a precursor (Wu et al., 1994). Hanigan et al. (1991) classified the red blood cell transport of citrulline and ornithine as being counter current and equal with the plasma free amino acid pool, respectively, based on arterial-venous differences in dairy cows. The red blood cells of pigs may have a similar role.

The amino acid and peptide transport systems across the intestinal mucosa of mammals have not been fully characterized or well understood (Webb, 1990; Webb and Bergman, 1991). In this context, there is still uncertainity about the role of plasma peptides in the absorption, exchange and transport of amino acids from portal vein-drained tissue, based on the substantial activity of proteases and peptidases in the intestinal lumen and cytosol of enterocytes (Webb, 1990). Flux of 
indispensable and dispensable amino acids into the plasma peptide pool of the portal vein blood of fed pigs was about one and a half and three times greater than for the plasma free amino acids, respectively. This indicates that a substantial proportion of the amino acids transported as plasma peptides were probably absorbed in a similar form from the lumen of the gastrointestinal tract. Growing pigs receiving an intraduodenal infusion of an enzymatic hydrolysate of milk protein, comprised primarily of small peptides, had greater and more rapid absorption of amino acids than pigs receiving an equivalent mixture of free amino acids (Rerat et al., 1988). The importance of peptide absorption from the portal vein-drained tissue was also reported in rats (Galibois et al., 1991) and Holstein steers (Koeln et al., 1993). In the present study, dietary glutamate must have been absorbed and transported in the form of plasma peptide based on the high concentration of this amino acids in wheat gluten and because of it's uptake by the gastrointestinal tract (Heitmann and Bergman, 1980; Koeln et al., 1993). There was a notable 2.7 times higher concentration of glutamate in the plasma peptide pool of portal vein blood of fed compared to unfed pigs. This difference suggest that a substantial proportion of glutamate, which has a high concentration in wheat gluten, was absorbed by the intestinal mucosa and transported as peptide. Glutamate and glycine accounted for 30.8 and $21.1 \%$, respectively, of the total flux of amino acids in the plasma peptide pool of the portal vein blood of fed pigs. Similarly, glutamate had the highest concentration in the diet at $40.6 \%$ of the amino acids reported. The corresponding concentration of glycine in the diet was $7.3 \%$. In this context, there was a positive relationship between the composition of amino acids exchanged into or out of the plasma peptide pool of portal vein blood of the fed pigs and the amino acid composition of the $\operatorname{diet}(\mathrm{r}=0.84, \mathrm{P}=0.0001)$. However, there was also a close relationship $(\mathrm{r}=0.75, \mathrm{P}=0.0014)$ to the composition of amino acids recovered from the terminal ileum of pigs fed wheat gluten as protein source ( $\mathrm{P}$. van Leeuwen, unpublished results). As such, amino acids of endogenous origin were also digested and absorbed from portal vein-drained tissues as peptides. Endogenous amino acid nitrogen recovered in the ileal digesta of pigs originates from salivary, pancreatic, bile and intestinal mucus secretions and epithelial cells (Souffrant, 1991). Of this endogenous nitrogen approximately $75 \%$ is digested and reabsorbed. Small intestinal and pancreatic secretions make the largest contributions to total endogenous nitrogen secretion at 57 and $17 \%$, respectively. The amino acids with a high concentration in ileal digesta of pigs fed wheat gluten typically also have a high concentration in pancreatic and intestinal mucus secretions. With the exception of amino acids that have a high concentration in endogenous mucus (e.g. Lien et al., 1997) such as threonine and serine or in pancreatic (e.g. Gabert et al., 1996) secretions such as glutamate, aspartate and the branched-chain amino acids, the proportion of amino acids in the diet and plasma peptide pool of the fed pigs more or less followed a similar pattern. Of course, these relationships do not 
take into account peptides from the metabolic activity of the portal vein-drained tissue that were exchanged into or out of the portal vein blood of the fed pigs. On the other hand, the concentration of amino acids in the plasma peptide pool of portal vein blood of the unfed pigs were usually lower than in their arterial blood. This suggest that the peripheral tissues of unfed pigs take over the role of the gastrointestinal tract for providing circulating plasma peptides to the liver. It could also be speculated that the substantial increase in the proportion of indispensable amino acids in the form of peptide in the arterial blood of unfed pigs represents a mobilization of tissues such as skeletal muscle to support the synthesis of essential proteins such as enzymes in the liver.

The highest proportion of total lysine and arginine in the portal vein blood of the fed pigs were in the plasma peptide pool. These amino acids have a high apparent digestibility because they are the first to be released from dietary protein by trypsin hydrolysis of peptide bonds next to basic amino acids (Low, 1980). A large proportion of the branched-chain amino acids were also in the peptide pool and this may be due to their early hydrolysis from dietary protein by chymotrypsin. Their apparent digestibility is also high relative to other amino acids (Low, 1980). In this context, amino acid digestibilities of dietary protein may partly depend on the proportion of the amino acids absorbed in the form of peptide.

\section{CONCLUSIONS}

The flux of amino acids into the portal vein blood of pigs fed wheat gluten as a protein source was quantitatively higher in the form of plasma peptides than plasma free amino acids. Red blood cells probably also have a role in the portal vein-drained tissue flux of amino acids. The flux of a large proportion of dietary amino acids into the portal vein blood of fed pigs was apparently in the form of peptides.

\section{ACKNOWLEDGEMENTS}

The authors wish to thank Dick van Kleef and Kasper Deuring for their assistance with surgery and care of the pigs. The assistance of Rolf Coolen and Annemarie van de Driessche with laboratory analysis is greatly appreciated. Thank-you to Christel Mols for her excellent preparation and layout of this manuscript. Financial support was provided by the TNO-Nutrition and Food Research Institute, Department of Animal Nutrition and Meat Technology and the Dutch Ministry of Agriculture, Nature Management and Fisheries. 


\section{REFERENCES}

Association of Official Analytical Chemists, 1990. Official Methods of Analysis. 15th Edition. Washington, DC

Boullin D.J., Crampton R.F., Heading C.E., Pelling D., 1973. Intestinal absorption of dipeptides containing glycine, phenylalanine, proline, $\beta$-alanine, or histidine in the rat. Clin. Sci. Mol. Med. $45,849-858$

Caine W.R., Tamminga S., Verstegen M.W.A., Sauer W.C., Schulze H., 1997. Endogenous recoveries and true ileal digestibilities of amino acids in newly weaned piglets fed diets with proteasetreated soybean meal. J. Anim. Sci. 75, 2970-2979

Centraal Veevoederbureau (CVB), 1998. Tables for Feedstuffs. Data on the Chemical Composition, Digestibility and Feeding Value of Feed Ingredients. Centraal Veevoederbureau, Lelystad (The Netherlands)

Elwyn D.H., 1966. Distribution of amino acids between plasma and red blood cells in the dog. Fed. Proc. 25, 854-861

Elwyn D.H., Parikh H.C., Shoemaker W.C., 1968. Amino acid movements between gut, liver and periphery in unanesthetized dogs. Amer. J. Physiol. 215, 1260-1275

Felig P., Wahren J., Raf L., 1973. Evidence of inter-organ amino acid transport by blood cells in humans. Proc. Nat. Acad. Sci. USA 70, 1775-1779

Gabert V.M., Sauer W.C., Li S., Fan M.Z., 1996. Exocrine pancreatic secretions in young pigs fed diets containing faba beans (Vicia faba) and peas (Pisum sativum): concentrations and flows of total, protcin-bound and free amino acids. J. Sci. Food Agric. 70, 256-262

Galibois I., Pitre F., Parent G., Savoie L., 1991. Analysis of bound amino acids in the plasma of fed rats: a new preparation procedure. J. Nutr. Biochem. 2, 25-30

Hanigan M. D., Calvert C. C., De Peters E. J., Reis B. L., Baldwin R. L., 1991. Whole blood and plasma amino acid uptakes by lactating bovinc mammary glands. J. Dairy Sci. 74, 2484-2490

Heitmann R. N., Bergman E. N., 1980. Transport of amino acids in whole blood and plasma of shecp. Amcr. J. Physiol. 239, E242-E247

Katz M. L., Bergman E. N., 1969. Simultaneous measurements of hepatic and portal venous blood flow in the sheep and dog. Amer. J. Physiol. 216, 946-952

Koeln L. L., Schlagheck T. G., Webb Jr., K. E., 1993. Amino acid flux across the gastrointestinal tract and liver of calves. J. Dairy Sci. 76, 2275-2285

Lien K. A., Sauer W. C., Fenton M., 1997. Recovery and composition of crude mucus in ileal digesta of pigs fed a protein-free diet. Z. Ernahrungswiss. 36, 182-190

Low A. G., 1980. Nutrient absorption in pigs. J. Sci. Food Agric. 31, 1087-1130

Rerat A., 1990. Absorption of nitrogen and amino acids from exogenous (fish meal proteins) or endogenous sources in the pig. Pig News Inf. 11, 173-180

Rerat A., Simoes Nunes C.. Mendy F, Roger L., 1988. Amino acid absorption and production of pancreatic hormones in non-anaesthetized pigs after duodenal infusions of a milk enzymic hydrolysate or free amino acids. Brit. J. Nutr. 60, 121-136

Sarwar G., Peace R. W., Botting H. G., Brule D., 1989. Digestibility of protein and amino acids in selected foods as determined by a rat balance method. Plants Food Hum. Nutr. 39, 23-32

Sauer W. C., Ozimek L., 1986. Digestibility of amino acids in swine: results and their practical applications. A review. Livest. Prod. Sci. 15, 367-388

Sedgwick G. W., Fenton T. W., Thompson J. R., 1991. Effect of protein precipitating agents on the recovery of plasma free amino acids. Can. J. Anim. Sci. 71, 953-957

Statistical Analysis System, 1990. SAS/STAT ${ }^{*}$ User's Guide (Release 6.08), Statistics. Cary, NC: SAS Institute Inc. 
Souffrant W. B., 1991. Endogenous nitrogen losses during digestion in pigs. In: M. W. A. Verstegen, J. Huisman, L. A. den Hartog (Editors). Digestive Physiology in Pigs: Endogenous losses during digestion in pigs. Proceedings of the 5th International Symposium on Digestive Physiology in Pigs. EAAP Publication No.54. Pudoc, Wageningen (The Netherlands), pp. 147-166

Steel R. G. D., Torrie J. H., 1980. Principles and Procedures of Statistics: A Biometrical Approach. 2nd Edition. McGraw-Hill Publishing Co., New York

van Kleef D. J., 1996. A new system for continuous intravenous infusion of pigs. Lab. Animals 30, 75-78 van Leeuwen P., Leuvenink H. G. D., Haasbroek W. M., Priem G., Bosch M., van Kleef D. J., 1995. A portal-vein-catheterization technique in pigs and sheep, and postprandial changes of $\mathrm{pO}_{2}$, $\mathrm{pCO}_{2}, \mathrm{pH}$, urea, ammonia, and creatinine and proteins in portal and arterial blood measured in pigs. J. Anim. Physiol. Anim. Nutr. 73, 38-46

Webb Jr., K. E., 1990. Intestinal absorption of protein hydrolysis products: A review. J. Anim. Sci. $68,30 ! 1-3022$

Webb Jr., K. E., Bergman E. N., 1991. Amino acid and peptide transport across the intestine. In: T. Tasada, Y. Sasaki, R. Kawashima (Editors). Physiological aspects of digestion and metabolism in ruminants. Procecdings of the 7th International Symposium on Ruminant Physiology. Academic Press, San Diego (USA), pp. 111-128

Wu G., Borbolla A. G., Knabe D. A., 1994. The uptake of glutamine and release of arginine, citrulline and proline by the small intestine of developing pigs. J. Nutr. 124, 2437-2444

Yen J. T., Killefer J., 1987. A method for chronically quantifying net absorption of nutrients and gut metabolites into hepatic portal vein in conscious swine. J. Anim. Sci. 64, 923-934

Young J. D., Ellory J. C., 1977. Substrate specificity of amino acid transport in sheep erythrocytes. Biochem. J. 162, 33-38

\section{STRESZCZENIE}

\section{Transport aminokwasów i peptydów poprzez tkanki do żyly wrotnej u świń}

Na rosnących świniach badano transport aminokwasów (AA) z tkanck do żyły wrotncj do i z puli wolnych AA w plazmie i w krwinkach oraz puli AA w peptydach plazmy. Cztery świnie $z$ cewnikami założonymi w tętnicy szyjnej oraz w żyłach wrotnej i krezkowej, żywiono dietą opartą na skrobi kukurydzianej z glutenem pszennym jako źródłem białka. Dawkę dzienną w ilości $2 \%$ masy ciała, zmieszaną z wodą ( $1: 2)$, podawano w dwóch równych częściach o godz. 8,00 i 16,00. Po 5 -dobowej adaptacji do diety, po karmieniu o godz. 8,00 świnie były głodzone przez 28 godz. Po 4 godz. (stan karmione) i po 28 godz. (stan głodzone) po podaniu paszy pobierano od każdej świni po $8 \mathrm{ml}$ krwi równocześnie z żyły wrotnej i z tętnicy szyjnej. Wielkość przepływu krwi była oznaczana metodą rozcieńczenia wskaźnika, stosując infuzję kwasu $p$-aminohipurowego do żyły krezkowej. Po 5 dniach powtómie pobrano krew i mierzono jej przepływ. Całkowity transport AA w plazmie żyły wrotncj u świń po karmieniu był wyższy $(\mathrm{P}=0,02)$, tak wolnych $\mathrm{AA}(55,7 \mathrm{mmol} / \mathrm{godz}$. $)$ jak i AA w peptydach $(123,2 \mathrm{mmol} / \mathrm{godz}$.) w porównaniu $\mathrm{z}$ transportem $\mathrm{u}$ świń głodzonych (odpowiednio 1,9 i-1,2 mmol/godz.). Ogólny transport AA w krwinkach u świń po karmieniu i głodzonych nie różnił się statystycznie $(\mathrm{P}=0,29) \mathrm{z}$ powodu dużego błędu standardowego związanego ze zmiennością pomiędzy zwierzętami oraz kumulującej się zmienności wyników analitycznych. Znaczna część AA w puli peptydów w plazmic żyły wrotnej świń po karmieniu pochodziła z diety, sądząc po profilu aminokwasów podobnym do ich profilu w glutenie pszennym. Otrzymane dane wskazują, że w plazmie żyły wrotnej pule wolnych AA i AA w peptydach, a prawdopodobnie i pula wolnych AA w krwinkach, są środkiem transportu AA $z$ tkanek penetrowanych przez krew przepływającą przez tę żyłę. 